\title{
New Summary Measures of the Foreign Exchange Value of the Dollar
}

Michael P. Leahy, of the Board's Division of International Finance, prepared this article. Suzette Applegate and Adam LaVier provided research assistance.

The multilateral trade-weighted index of the foreign exchange value of the U.S. dollar against the currencies of the other countries in the Group of Ten (G-10), developed at the Federal Reserve Board in 1971, has played an important role in staff analysis of foreign influences on the U.S. economy for more than twenty-five years. ${ }^{1}$ However, changes in international trading relationships and in the structure of international financial markets have led to increased interest in the currencies of U.S. trading partners outside the G-10 countries. Furthermore, the establishment of the European Economic and Monetary Union (EMU) is bringing about significant changes inside the G-10 countries, with the euro, which will be introduced in January 1999, ultimately replacing five of the G-10 currencies. Consideration of these developments has prompted taking a fresh look at ways to measure the foreign exchange value of the dollar. As a result, members of the Board's staff have developed several new indexes of the dollar's overall foreign exchange value.

In general, an index of the foreign exchange value of a currency is intended to distill into a single number key information from often divergent movements in bilateral exchange rates. As with a price index, an exchange rate index can be created in a variety of ways. The design of an exchange rate index-both which currencies to include and how to weight them-depends on its specific purpose. Although the process of compressing individual currency information into one number inevitably results in the loss of some information, a well-

1. Since January 1977 , this index has been published in table 3.28 of the statistical appendix to the Federal Reserve Bulletin. Discussions of the index have appeared in various issues of the Bulletin: See "Index of the Weighted-Average Exchange Value of the U.S. Dollar: Revision," vol. 64 (August 1978), p. 700; Peter Hooper and John Morton, "Summary Measures of the Dollar's Foreign Exchange Value," vol. 64 (October 1978), pp. 783-89; and B. Dianne Pauls, "Measuring the Foreign-Exchange Value of the Dollar," vol. 73 (June 1987), pp. 411-22. designed index will preserve information that is critical for its purpose.

Exchange rate indexes can have various uses. They can play a role in the analysis of the price competitiveness of domestic goods relative to foreign goods, the effect of foreign economic and financial developments on the domestic price level, and the demand for domestic and foreign currency assets. The G-10 index, which was developed when the Bretton Woods system of fixed exchange rates first broke down, was designed to serve as a summary measure of the dollar's movements against the currencies of ten other major foreign countries that participated in the Smithsonian Accord of December 1971. Over the years, the index has been used for a variety of purposes, but it has functioned mainly as a tool in the analysis of how changes in the foreign exchange value of the dollar influence U.S. international trade. In this index, the ten bilateral dollar exchange rates are aggregated using multilateral trade shares, which are viewed as reflecting the relative importance of each country as a competitor in world markets.

Like the G-10 index, the new indexes are designed principally to measure competitiveness in world markets. However, the new indexes are created with a different weighting scheme that focuses more directly on the competitiveness of U.S. goods in U.S. and foreign markets. In addition, the new indexes summarize and characterize the dollar's movements in foreign exchange markets against a broader set of currencies and are designed to take account of the changing structure of trade patterns and exchange rates.

\section{THE NEW INDEXES}

The new indexes of the dollar's overall foreign exchange value have been developed for three currency groups, and for each group nominal and real (price-adjusted) indexes have been created. The first, and primary, group is that of the currencies of important U.S. trading partners. This group is the basis for the construction of what the staff terms the broad index of the dollar's foreign exchange value. The 
broad index includes thirty-five currencies until the beginning of Stage III of EMU on January 1, 1999. ${ }^{2}$ At that time, the euro will replace the ten euro-area currencies, and the broad index will have twenty-six currencies. $^{3}$

The other two groups are subsets of the broad index currencies. One of these comprises the major international currencies-those of the euro-area countries and Australia, Canada, Japan, Sweden, Switzerland, and the United Kingdom. These are used in the construction of what is termed the major currency index. It includes sixteen currencies until the introduction of the euro in January $1999 .{ }^{4}$ After that, the index will become a seven-currency index.

The third group comprises the remaining currencies. In this group are the currencies of important U.S. trading partners, but these currencies are not heavily traded outside their home markets. This group is used to construct what the staff terms the other important trading partner (OITP) index. It includes the currencies of nineteen major U.S. trading partners: Argentina, Brazil, Chile, Colombia, Mexico, and Venezuela in Latin America; China, Hong Kong, India, Indonesia, Korea, Malaysia, the Philippines, Singapore, Taiwan, and Thailand in Asia; Israel and Saudi Arabia in the Middle East; and Russia in Eastern Europe.

The major currency indexes-nominal and realhave a path similar to that of the comparable G-10 indexes over the same period, although the swings in the new series are less extreme (charts 1 and 2). The nominal broad and OITP indexes move quite differently from the major currency index because of the inclusion of currencies of some high-inflation countries that have experienced persistent depreciations. The inclusion of such countries restricts the usefulness of the nominal versions of these indexes to analysis of shorter-term developments in foreign exchange markets because, over the longer term, large nominal depreciations of a few currencies swamp information on the value of the dollar against other currencies. The real versions of the broad and OITP indexes compensate for these depreciations, although the real OITP index yields a value of the dollar that is consistently higher than the value in the broad index after the mid-1980s.

2. Because of the existing monetary union between Belgium and Luxembourg, the Belgian/Luxembourg franc is treated as one currency in this accounting.

3. The euro-area countries are Austria, Belgium, Finland, France, Germany, Ireland, Italy, Luxembourg, the Netherlands, Portugal, and Spain.

4. The Belgian/Luxembourg franc is again treated as one currency.
1. Nominal indexes of the foreign exchange value of the U.S. dollar, January 1973-September 1998

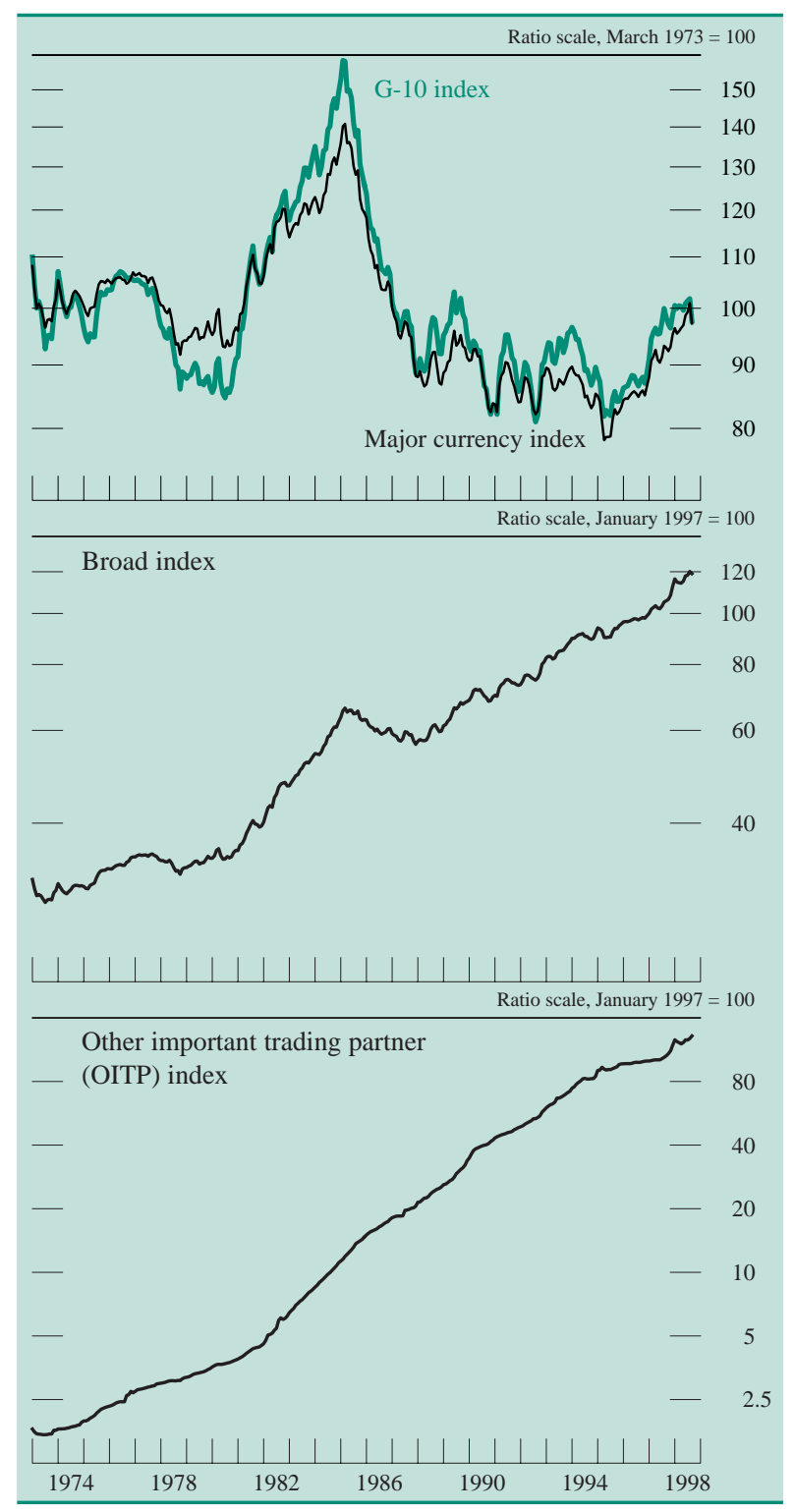

Note. The data are monthly.

The three indexes employ a common weighting scheme. Market shares of U.S. goods in foreign markets and foreign goods in U.S. and third-country markets are used to construct the currency weights for the broad index. These weights are updated annually to incorporate changes in trade patterns. We derive the weights for the major currency and OITP indexes from the broad index weights by simply rescaling the broad index weights so that the weights of the currencies included in each subindex sum to one (table 1).

The major currency and broad indexes currently give considerably more weight to the Canadian dollar 
2. Real (price-adjusted) indexes of the foreign exchange value of the U.S. dollar, January 1973-September 1998

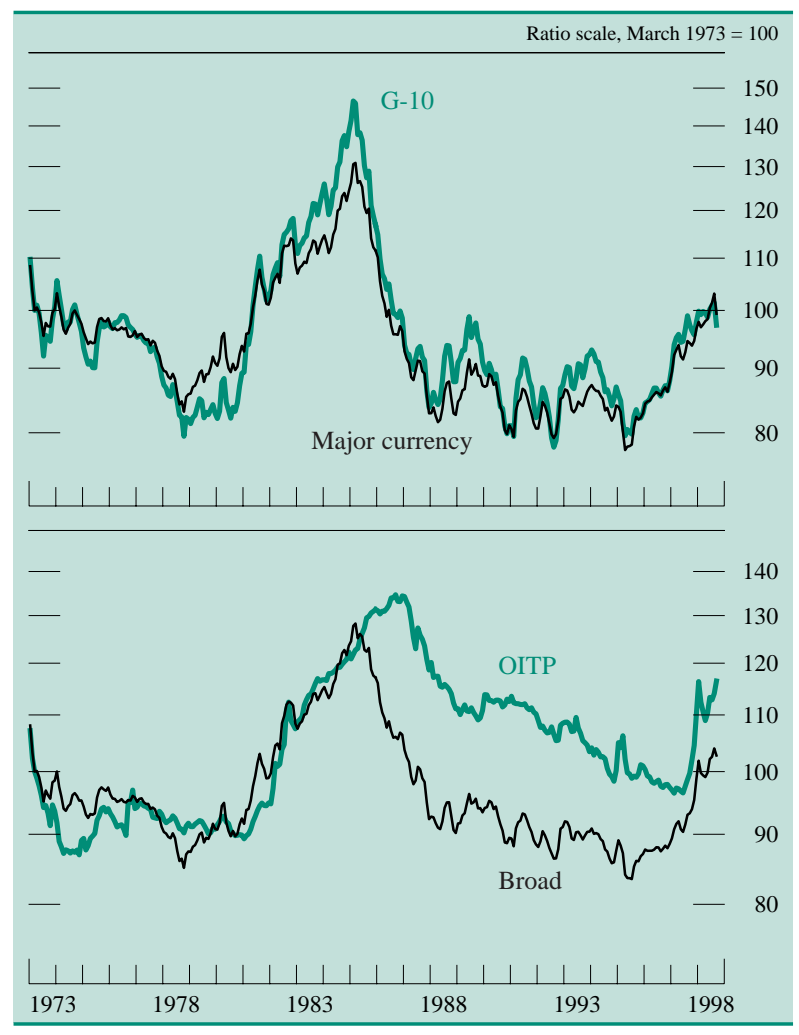

Note. The data are monthly.

and the Japanese yen than the G-10 index does, with offsetting declines in the weights for the euro-area currencies. These shifts reflect the growth of Japan as a U.S. trading partner since the mid-1970s and the change from a multilateral trade-weighting scheme, with equal weight given to global trade in any market, to one that gives more weight to trade in markets that are important to the United States. These shifts also reflect the exclusion from the new weights of intra-European Union (EU) trade, which was included in the multilateral trade weights.

\section{CURRENCY SELECTION}

The basic strategy in selecting which currencies to include in the new indexes was to expand the currency coverage from that of the G-10 index by including the currencies of a larger set of important U.S. trading partners. The new indexes were also designed to accommodate the introduction of the euro.

\section{The Broad Index}

Shares in U.S. trade largely determined the currency selection for the broad index. The currencies of all
1. 1997 trade weights for the new U.S. dollar indexes and 1972-76 multilateral trade weights for the G-10 index Percent

\begin{tabular}{|c|c|c|c|c|}
\hline Country or region & Broad & $\begin{array}{c}\text { Major } \\
\text { currency }\end{array}$ & OITP & G-10 \\
\hline Canada & 17.3 & 30.3 & . & 9.1 \\
\hline Euro area & 16.4 & 28.7 & $\ldots$ & 57.6 \\
\hline Japan ..... & 14.6 & 25.6 & & 13.6 \\
\hline Mexico & 8.6 & & 19.9 & \\
\hline China $\ldots \ldots \ldots$. & 6.6 & & 15.3 & \\
\hline United Kingdom & 4.6 & 8.0 & & 11.9 \\
\hline Taiwan ........... & 3.9 & & 9.1 & \\
\hline Korea . & 3.7 & . & 8.6 & . \\
\hline Singapore & 3.1 & & 7.2 & . \\
\hline Hong Kong & 2.8 & $\therefore$ & 6.6 & \\
\hline Malaysia . & 2.4 & $\therefore$ & 5.5 & . \\
\hline Brazil .... & 1.9 & & 4.4 & $\cdots$ \\
\hline Switzerland & 1.8 & 3.2 & $\ldots$ & 3.6 \\
\hline Thailand & 1.7 & & 3.9 & . \\
\hline Australia & 1.5 & 2.6 & & \\
\hline Indonesia & 1.3 & & 3.0 & \\
\hline Philippines & 1.2 & . & 2.7 & . \\
\hline Russia .... & .9 & $\therefore$ & 2.2 & . \\
\hline India . & .9 & & 2.2 & \\
\hline Sweden & .9 & 1.6 & & 4.2 \\
\hline Saudi Arabia & .9 & & 2.1 & \\
\hline Israel ........ & .9 & $\therefore$ & 2.1 & $\therefore$ \\
\hline Argentina & .6 & $\cdots$ & 1.5 & $\therefore$ \\
\hline Venezuela & .6 & . & 1.4 & $\ldots$ \\
\hline Chile ..... & .5 & . & 1.3 & . \\
\hline Colombia & .5 & . & 1.1 & . \\
\hline Total & 100 & 100 & 100 & 100 \\
\hline $\begin{array}{l}\text { Mемо } \\
\text { Euro-area countries }\end{array}$ & & & & \\
\hline Germany $\ldots \ldots \ldots \ldots$ & 5.6 & 9.9 & $\ldots$ & 20.8 \\
\hline France ...... & 2.9 & 5.0 & $\ldots$ & 13.1 \\
\hline Italy .. & 2.5 & 4.5 & $\ldots$ & 9.0 \\
\hline Netherlands & 1.5 & 2.7 & $\ldots$ & 8.3 \\
\hline Belgium/Luxembourg & 1.4 & 2.5 & $\ldots$ & 6.4 \\
\hline Spain $\ldots \ldots \ldots \ldots \ldots$ & .8 & 1.4 & $\cdots$ & \\
\hline Ireland . & .7 & 1.3 & $\ldots$ & \\
\hline Austria & .4 & .7 & $\ldots$ & \\
\hline Finland & .3 & .6 & & \\
\hline Portugal & .1 & .2 & . & \\
\hline Total & 16.4 & 28.7 & $\ldots$ & 57.6 \\
\hline
\end{tabular}

NotE. Broad index weights for previous years will be available on the Board's web site (http://www.federalreserve.gov). Components may not sum to totals because of rounding.

foreign countries or regions that had a share of U.S. non-oil imports or nonagricultural exports of at least $1 / 2$ percent in 1997 are included in the broad indexes, as rankings of U.S. trading partners by share of U.S. trade in that year show (tables 2, 3, and 4).

The countries with currencies in the broad index are also important in global trade (table 5). The countries and regions whose currencies are included in the indexes generate more than 75 percent of the world's gross national product (outside the United States), measured on the basis of purchasing power parity (table 6). The list of currencies included in the broad index will be re-evaluated annually when the currency weights are updated.

\section{The Major Currency Index}

The major currency index was designed to serve many of the same purposes that the G-10 index of the 
2. U.S. non-oil imports, by country or region, 1997

\begin{tabular}{|c|c|c|}
\hline Country or region & $\begin{array}{c}\text { Level } \\
\text { (billions of } \\
\text { U.S. dollars) }\end{array}$ & $\begin{array}{l}\text { Share of } \\
\text { U.S. non-oil } \\
\text { imports } \\
\text { (percent) }\end{array}$ \\
\hline Canada & 156.189 & 19.55 \\
\hline Japan . & 121.551 & 15.21 \\
\hline Euro area & 113.252 & 14.18 \\
\hline Mexico ... & 77.487 & 9.70 \\
\hline China . & 62.099 & 7.77 \\
\hline Taiwan & 32.628 & 4.08 \\
\hline United Kingdom & 30.524 & 3.82 \\
\hline Korea .......... & 23.040 & 2.88 \\
\hline Singapore . & 19.940 & 2.50 \\
\hline Malaysia . & 17.820 & 2.23 \\
\hline Thailand & 12.592 & 1.58 \\
\hline Philippines & 10.444 & 1.31 \\
\hline Hong Kong & 10.288 & 1.29 \\
\hline Brazil & 9.454 & 1.18 \\
\hline Indonesia & 8.730 & 1.09 \\
\hline Switzerland & 8.496 & 1.06 \\
\hline Israel ....... & 7.320 & .92 \\
\hline India $\ldots .$. & 7.302 & .91 \\
\hline Sweden & 7.182 & .90 \\
\hline Australia & 4.223 & .53 \\
\hline Russia ... & 4.199 & .53 \\
\hline Colombia & 2.666 & .33 \\
\hline Chile ... & 2.284 & .29 \\
\hline Argentina & 1.641 & .21 \\
\hline Venezuela & 1.639 & .21 \\
\hline Saudi Arabia . & .548 & .07 \\
\hline \multicolumn{3}{|l|}{ Мемо } \\
\hline Broad index group & 753.538 & 94.32 \\
\hline Major currency group & 441.417 & 55.25 \\
\hline OITP group...$\ldots \ldots$ & 312.122 & 39.07 \\
\hline G-10 $\ldots \ldots \ldots$ & 421.332 & 52.74 \\
\hline
\end{tabular}

Note. In this table and those that follow, components may not sum to memo items because of rounding.

Source. U.S. Department of Commerce, Bureau of Economic Analysis.

3. U.S. nonagricultural exports, by country or region, 1997

\begin{tabular}{|c|c|c|}
\hline Country or region & $\begin{array}{c}\text { Level } \\
\text { (billions of } \\
\text { U.S. dollars) }\end{array}$ & $\begin{array}{l}\text { Share of U.S. } \\
\text { nonagricultural } \\
\text { exports } \\
\text { (percent) }\end{array}$ \\
\hline Canada & 143.210 & 23.28 \\
\hline Euro area & 89.655 & $\begin{array}{l}25.20 \\
14.57\end{array}$ \\
\hline Mexico .. & 65.776 & 10.69 \\
\hline Japan & 54.029 & 8.78 \\
\hline United Kingdom & 33.326 & 5.42 \\
\hline Korea $\ldots \ldots \ldots \ldots$ & 21.634 & 3.52 \\
\hline Singapore $\ldots \ldots \ldots \ldots$ & 17.255 & 2.80 \\
\hline Taiwan .. & 16.483 & 2.68 \\
\hline Brazil . & 15.268 & 2.48 \\
\hline Hong Kong .. & 13.170 & 2.14 \\
\hline Australia .......... & 11.558 & 1.88 \\
\hline China ...... & 11.107 & 1.81 \\
\hline Malaysia ..... & 9.855 & 1.60 \\
\hline Philippines & 6.506 & 1.06 \\
\hline Thailand ... & 6.457 & 1.05 \\
\hline Saudi Arabia & 6.408 & 1.04 \\
\hline Venezuela ............ & 5.967 & .97 \\
\hline Argentina ......... & 5.420 & .88 \\
\hline Switzerland & 4.775 & .78 \\
\hline Israel $\ldots \ldots \ldots$ & 4.636 & .75 \\
\hline Colombia ....... & 4.612 & .75 \\
\hline Chile .... & 4.222 & .69 \\
\hline Indonesia & 3.733 & .61 \\
\hline India $\ldots . . .$. & 3.432 & .56 \\
\hline Sweden ... & 3.053 & .50 \\
\hline Russia . & 2.130 & .35 \\
\hline \multicolumn{3}{|l|}{ Мемо } \\
\hline Broad index group & 563.676 & 91.63 \\
\hline Major currency group & 339.605 & 55.20 \\
\hline OITP group ........... & 224.070 & 36.42 \\
\hline $\mathrm{G}-10 \quad \ldots \ldots \ldots \ldots$ & 315.351 & 51.26 \\
\hline
\end{tabular}

NoTE. Nonagricultural exports exclude military exports and gold. SourCE. U.S. Department of Commerce, Bureau of Economic Analysis. dollar's foreign exchange value served in the past. Like the G-10 index, the major currency index not only measures the competitiveness of U.S. goods relative to goods of the major industrial countries, it also serves as a gauge of financial pressures on the dollar. As a consequence, the index includes currencies traded in deep and relatively liquid financial markets and for which short- and long-term interest rates are readily available: the currencies of the G-10 countries and of the other countries of the euro area and the Australian dollar.

One benefit of this currency group is that it excludes currencies of trading partners with a history of high inflation relative to the United States. Thus it provides a useful gauge of the dollar's foreign exchange value in nominal terms for tracking both day-to-day and longer-term developments. Currencies of economies subject to high inflation pose a problem in the construction of a nominal exchange rate index: Because the large depreciations of those currencies tend to dominate the index, the contributions of movements in the dollar's nominal value against other currencies become relatively insignificant.

4. U.S. non-oil imports and nonagricultural exports, by country or region, 1997

\begin{tabular}{|c|c|c|}
\hline Country or region & $\begin{array}{c}\text { Level } \\
\text { (billions of } \\
\text { U.S. dollars) }\end{array}$ & $\begin{array}{l}\text { Share of U.S. } \\
\text { non-oil imports and } \\
\text { nonagricultural } \\
\text { exports } \\
\text { (percent) }\end{array}$ \\
\hline Canada & 299.399 & 21.17 \\
\hline Euro area & 202.907 & 14.35 \\
\hline Japan ..... & 175.580 & 12.42 \\
\hline Mexico & 143.263 & 10.13 \\
\hline China .. & 73.206 & 5.18 \\
\hline United Kingdom & 63.850 & 4.52 \\
\hline Taiwan ......... & 49.111 & 3.47 \\
\hline Korea ........... & 44.674 & 3.16 \\
\hline Singapore & 37.195 & 2.63 \\
\hline Malaysia. & 27.675 & 1.96 \\
\hline Brazil .... & 24.722 & 1.75 \\
\hline Hong Kong . & 23.458 & 1.66 \\
\hline Thailand .... & 19.049 & 1.35 \\
\hline Philippines & 16.950 & 1.20 \\
\hline Australia .. & 15.781 & 1.12 \\
\hline Switzerland & 13.271 & .94 \\
\hline Indonesia .. & 12.463 & .88 \\
\hline Israel ....... & 11.956 & .85 \\
\hline India $\ldots \ldots$ & 10.734 & .76 \\
\hline Sweden .... & 10.235 & .72 \\
\hline Argentina & 7.061 & .50 \\
\hline Saudi Arabia & 6.956 & .49 \\
\hline Chile ....... & 6.506 & .46 \\
\hline Russia & 6.329 & .45 \\
\hline Venezuela .. & 5.967 & .42 \\
\hline Colombia ... & 4.612 & .33 \\
\hline \multicolumn{3}{|l|}{ Мемо } \\
\hline Broad index group & 1317.214 & 93.15 \\
\hline Major currency group & 781.022 & 55.23 \\
\hline OITP group ........... & 536.192 & 37.92 \\
\hline G-10 $\ldots \ldots$ & 736.683 & 52.10 \\
\hline
\end{tabular}

Note. Nonagricultural exports exclude military exports and gold. SourCE. U.S. Department of Commerce, Bureau of Economic Analysis. 


\section{The Other Important Trading Partner Index}

The OITP index captures movements of the dollar against the currencies of key U.S. trading partners in Latin America, Asia, the Middle East, and Eastern Europe. These currencies account for more than 40 percent of the weight in the broad index in recent years, and indexes including them provide important measures of the competitiveness of U.S. goods in those regions and of goods from those regions in the United States. Because some of these economies have experienced episodes of hyperinflation, the nominal OITP index is likely to be most useful in analyzing shorter-term developments in dollar exchange rates. The price-adjusted version of this index can provide a useful summary of longer-term currency developments.

\section{THE WEIGHTING SCHEME}

The weighting scheme used in the construction of the indexes is based on a measure of trade competitiveness. In this measure, the importance of changes in the exchange value of a given foreign currency depends on the share of the foreign country's goods

5. Multilateral non-U.S. trade shares, 1996

Percent of world trade

\begin{tabular}{|c|c|c|}
\hline \multirow{2}{*}{ Country or region } & \multicolumn{2}{|c|}{ Trade share } \\
\hline & $\begin{array}{l}\text { Including } \\
\text { intra-EU trade }\end{array}$ & $\begin{array}{c}\text { Excluding } \\
\text { intra-EU trade }\end{array}$ \\
\hline Euro area & 34.73 & 14.62 \\
\hline Japan .... & 8.23 & 9.25 \\
\hline Hong Kong & 4.10 & 4.61 \\
\hline Canada ...... & 4.01 & 4.50 \\
\hline China ...... & 3.14 & 3.53 \\
\hline Korea . & 3.04 & 3.42 \\
\hline United Kingdom & 5.86 & 3.22 \\
\hline Singapore ........ & 2.78 & 3.12 \\
\hline Taiwan ......... & 2.34 & 2.63 \\
\hline Mexico & 2.01 & 2.26 \\
\hline Switzerland & 1.71 & 1.92 \\
\hline Malaysia ........ & 1.70 & 1.91 \\
\hline Thailand .... & 1.40 & 1.57 \\
\hline Russia & 1.39 & 1.56 \\
\hline Australia $\ldots \ldots \ldots \ldots \ldots$ & 1.32 & 1.48 \\
\hline Brazil ..... & 1.15 & 1.30 \\
\hline Indonesia & 1.01 & 1.13 \\
\hline Saudi Arabia & .92 & 1.03 \\
\hline India $\ldots \ldots \ldots \ldots$ & .74 & .83 \\
\hline Sweden ..... & 1.63 & .73 \\
\hline Philippines . & .57 & .64 \\
\hline Israel ...... & .54 & .61 \\
\hline Argentina & .52 & .58 \\
\hline Venezuela & .37 & .42 \\
\hline Chile ..... & .36 & .40 \\
\hline Colombia . & .27 & .30 \\
\hline \multicolumn{3}{|l|}{ Мемо } \\
\hline Broad index group & 85.84 & 67.57 \\
\hline Major currency group & 57.50 & 35.73 \\
\hline OITP group...$\ldots \ldots$ & 28.34 & 31.84 \\
\hline G-10 $\ldots$. & 50.15 & 32.00 \\
\hline
\end{tabular}

Source. International Monetary Fund, Direction of Trade Statistics and International Financial Statistics. in all the markets that are important to U.S. producers. To the extent that a country's goods are important in those markets, that country's currency will be heavily weighted in the index.

Competition between U.S. goods and the goods of a particular foreign country can be thought of as taking place in the United States or in foreign markets. For competition in the United States, a weight equal to a country's share of U.S. imports is used as a proxy for the degree of competition from that country.

Competition in foreign markets can be decomposed into competition in the foreign country's home market and competition in third-country markets. Two kinds of weights correspond to the two venues for competition abroad. A weight equal to a country's share in U.S. exports is used to measure the extent to which U.S. goods compete directly with a foreign country's goods in that country's home market. A

6. Purchasing power parity GNP and non-U.S. GNP shares for selected countries, 1995

\begin{tabular}{|c|c|c|}
\hline Country or region & $\begin{array}{c}\text { Purchasing power } \\
\text { parity GNP } \\
\text { (billions of } \\
\text { U.S. dollars) }\end{array}$ & $\begin{array}{l}\text { Share of } \\
\text { world GNP } \\
\text { (percent) }\end{array}$ \\
\hline Euro area & $5,553.651$ & 20.05 \\
\hline China . & $3,504.584$ & 12.65 \\
\hline Japan & $2,768.172$ & 9.99 \\
\hline India & $1,301.160$ & 4.70 \\
\hline United Kingdom ... & $1,126.710$ & 4.07 \\
\hline Brazil ........... & 859.680 & 3.10 \\
\hline Indonesia & 734.540 & 2.65 \\
\hline Russia .... & 663.936 & 2.40 \\
\hline Canada ...... & 625.448 & 2.26 \\
\hline Mexico & 587.520 & 2.12 \\
\hline Korea & 514.105 & 1.86 \\
\hline Thailand & 438.828 & 1.58 \\
\hline Australia & 342.814 & 1.24 \\
\hline Turkey ${ }^{1}$. & 340.938 & 1.23 \\
\hline Taiwan $\mathrm{e}^{\circ}$ & 289.394 & 1.04 \\
\hline Argentina ... & 288.357 & 1.04 \\
\hline Colombia & 225.584 & .81 \\
\hline Philippines & 195.510 & .71 \\
\hline Malaysia .. & 181.302 & .65 \\
\hline Switzerland . & 181.020 & .65 \\
\hline Venezuela & 171.430 & .62 \\
\hline Saudi Arabia ${ }^{2}$ & 168.744 & .61 \\
\hline Sweden ....... & 163.152 & .59 \\
\hline Hong Kong ... & 142.290 & .51 \\
\hline Chile ...... & 135.184 & .49 \\
\hline Greece $^{1}$ & 122.955 & .44 \\
\hline Denmark $^{1}$ & 110.396 & .40 \\
\hline Norway $^{1}$. & 96.536 & .35 \\
\hline Israel $\ldots$ & 90.695 & .33 \\
\hline Singapore & 68.310 & .25 \\
\hline Total of above & $21,992.945$ & 79.40 \\
\hline \multicolumn{3}{|l|}{ Мемо } \\
\hline Broad index group & $21,322.120$ & 76.98 \\
\hline Major currency group & $10,760.967$ & 38.85 \\
\hline OITTP group ............ & $10,561.153$ & 38.13 \\
\hline G-10 & $9,394.633$ & 33.92 \\
\hline
\end{tabular}

1. Country with currency not included in exchange rate index

2. As of 1994.

e Estimated.

Source. World Bank, World Development Report 1997. World GNP estimate derived from share of U.S. GDP in world GDP from table A in International Monetary Fund, World Economic Outlook, May 1998, p. 133. 
second type of export weight is constructed to account for the extent to which a particular foreign country's exports go to third-country markets that are also destinations for U.S. exports, as would be the case when U.S. goods compete with German goods in Japan. This type of competition is measured as the product of Germany's share in Japan's imports and the share of U.S. exports going to Japan. In this way a country will have a high combined export weight if it figures prominantly as a direct destination for U.S. exports or is a major exporter to other countries that take a large share of U.S. exports. The weight in the summary index is then computed as the simple average of the bilateral import share weights and the combined export weights. The appendix contains further details on the construction of these weights.

\section{INDEX FORMULA AND DATA}

The new exchange rate indexes incorporate weights that vary over time. The formula for each nominal exchange rate index, $I_{t}$, is given by

$$
I_{t}=I_{t-1} \prod_{j}\left(e_{j, t} / e_{j, t-1}\right)^{w_{j, t},}
$$

where $e_{j, t}$ is the price of the U.S. dollar in terms of foreign currency $j$ at time $t$, and $w_{j, t}$ is the weight of currency $j$ at time $t$ in the total competitiveness index for the U.S. dollar. The base-period value of the index, $I_{0}$, is assumed to take an arbitrary valuetypically equal to 100 - at an arbitrary time. Replacing the nominal exchange rates, $e_{j, t}$, with their real counterparts, $e_{j, t} p_{t} / p_{j, t}$, where $p_{t}$ is the consumer price index (CPI) for the United States at time $t$ and $p_{j, t}$ is the CPI for country $j$ at time $t$, yields the formula for the real exchange rate index. Thus, the indexes are constructed so that an appreciation of the dollar corresponds to higher index values. ${ }^{5}$

One benefit of using a formula that allows for the weights on the exchange rates to vary over time is that the index can incorporate changes in the pattern of trade, such as the expansion of trade with China or other Asian economies, which would not be captured in a fixed-weight index. In addition, adjustable weights permit adaptation to events such as the accession of a second wave of EU countries to the EMU, which would change the trade shares assigned to currencies in the indexes. Currencies of countries

5. Summary indexes of the foreign exchange value of any other currency could be computed in a similar fashion by using trade data to determine the weights and by using exchange rates for that currency instead of the dollar. with dramatic increases or decreases in trade shares in markets that are important to the United States could be added or subtracted from the index as the weights are revised.

Because the new indexes are intended to be measures of trade competitiveness, the data used to compute the import and export shares for the United States for the most part exclude U.S. military exports and trade in primary commodities. Trade competitiveness is unlikely to play an important role in the determination of U.S. military exports, and the country of origin or destination is relatively unimportant in the pricing of primary commodities, which are largely homogeneous and are priced in world auction markets based on global supply and demand. In the calculation of the weights, the shares of U.S. imports and exports are bilateral non-oil import shares and bilateral nonagricultural export shares adjusted to exclude U.S. gold and military exports. Comparably disaggregated trade data for other countries are not as readily available. Therefore, the import and export shares used in the calculation of third-country effects are based on aggregate imports and exports for each country pair. Because of the impending move into monetary union by eleven of the EU member countries and the highly integrated trading relationships among the remaining EU countries, the calculations exclude intra-EU trade. All of these trade shares are updated annually to incorporate changes in patterns of trade. In addition, events such as the expansion of the euro zone to include other EU countries-which would naturally change the trade shares for the euro and, as a by-product, the other currencies in the indexes - will lead to an adjustment of the weights on the date of such events.

\section{OTHER ISSUES}

Index revisions and publication policies are two other issues associated with the development of the new indexes.

\section{Index Revisions}

Because the weights for the G-10 exchange rate index are fixed, revisions to that index were not necessary. The new indexes, however, will be subject to revision, particularly in the current year and the year immediately preceding the current year, because the data used to construct the weights in the new indexes are released with a lag and are periodically revised. For example, in February 1999, a January 
1999 index value (or a value for a particular day in the month) would be calculated using trade data for 1997, because trade data for all of 1998 or for 1999 will not have been released. Later in 1999, after the trade data for 1998 are available, the January 1999 index value will be updated using 1998 weights, as will all of the 1998 index values. At some point in 2000, the trade data for 1999 will be released, and a second revision to the January 1999 index value will be made. Thus, recent index values for the first part of any year are likely to be revised at least two times. Subsequent revisions will occur if historical values for trade data are revised. The weights used in the indexes will normally be revised and updated on an annual schedule. Earlier historical values may also be revised from time to time.

Revisions to the foreign CPIs used in the calculation of the real exchange rate indexes will also prompt revisions to the real exchange rate indexes. Because CPIs for some countries are released with a considerable lag, recent months will be estimated by applying the most recent twelve-month percent change that is available. Those estimates will eventually be replaced by published data when they become available.

\section{Publication}

The new indexes will be published on the Board's web site (http://www.federalreserve.gov) and, beginning with this issue, in the Federal Reserve Bulletin. ${ }^{6}$ We will continue to publish the G-10 index in the Bulletin for a few more months but will discontinue publication with the release of the December value for the index, which will appear in the February 1999 issue. The broad index weights used in the construction of the new indexes and the underlying exchange rate data will also be made available on the Board's web site.

\section{APPENDIX: A FORMAL PRESENTATION OF THE WEIGHTING SCHEME}

A stylized trade model is the basis for the weighting scheme. Behavior in this model is characterized by a set of symmetric import demand expressions for the home country and a number of foreign countries. After having imposed some simplifying assumptions relating to the functional form of the demand equations and the symmetry and constancy of various elasticities, one can formulate the weights with which

6. See table 3.28, "Foreign Exchange Rates," p. A62. to aggregate foreign prices and exchange rates as functions of market shares alone, independent of the structural parameters of the demand system. ${ }^{7}$

The construction of the weights can be represented as a two-stage process. In the first stage, the market shares attributable to a given foreign country's goods are determined for the U.S. market, the foreign country's home market, and third-country markets. In the second stage, these individual market shares are averaged according to the share of U.S. goods going to each market. Formally, the weight, $W_{U S, k}$, of country $k$ in a total competitiveness index for the United States is an average of the market shares, $m_{j, k}$, of goods from country $k$ relative to total sales in each country $j$ :

$$
W_{U S, k}=\sum_{j} x_{U S, j} m_{j, k},
$$

where $x_{U S, j}$ is the share of goods produced in the United States and sold in market $j$ relative to all goods produced in the United States.

As an example, let Japan be country $k$. Then, the total competitiveness weight, $W_{U S, k}$, for the yen in the U.S. dollar index is an average of the market shares of Japanese goods in total sales in the United States, in Japan, and in all other countries. This average is computed after weighting each market demand share by its corresponding U.S. production share to incorporate into the weight the importance of the market to U.S. producers.

With the introduction of some further notation, these weights can be written in terms of import and export shares. Let $\mu_{j, k}$ be the share of country $j$ imports purchased from country $k$. For $j \neq k$, it can be shown that $\mu_{j, k}=m_{j, k} /\left(1-m_{j, j}\right)$. Because a country does not import from itself, $\mu_{j, j}$ is undefined. Similarly, let $\epsilon_{U S, j}$ be the share of U.S. exports sold in country $j$. For $j \neq U S$, it can be shown that $\epsilon_{U S, j}=x_{U S, j} /\left(1-x_{U S, U S}\right)$. Because the United States does not export to itself, $\epsilon_{U S, U S}$ is undefined. With this notation, the weight, $W_{U S, k}$, of country $k$ in a total competitiveness index for the United States can be rewritten in terms of import and export shares:

$$
\begin{aligned}
W_{U S, k}= & x_{U S, U S}\left(1-m_{U S, U S}\right) \mu_{U S, k} \\
& +\left(1-x_{U S, U S}\right) m_{k, k} \epsilon_{U S, k} \\
& +\left(1-x_{U S, U S}\right) \sum_{\substack{j \neq U S \\
j \neq k}} \epsilon_{U S, j} \mu_{j, k}\left(1-m_{j, j}\right)
\end{aligned}
$$

7. For details, see Anne K. McGuirk, "Measuring Price Competitiveness for Industrial Country Trade in Manufactures," International Monetary Fund working paper WP/87/34 (1986). 
As equation 2 shows, the weights can be decomposed into three submeasures of competitiveness. The first term characterizes the effect of competition in the United States between the goods of the United States and country $k$. This term is a function of country $k$ 's share in U.S. imports, $\mu_{U S, k}$. The second term describes the effect of competition between the goods of the United States and country $k$ in the home market of country $k$. This term is a function of country $k$ 's share in U.S. exports, $\epsilon_{U S, k}$. The third term captures the effect of competition between the goods of the United States and country $k$ in the markets of third countries, where the summation averages the shares of country $k$ goods in third-country imports weighted by U.S. export shares to the third-country markets. For convenience, let $\tau_{U S, k}$ represent this averaging of export and import shares in third countries:

$$
\tau_{U S, k}=\sum_{\substack{j \neq U S \\ j \neq k}} \epsilon_{U S, j} \mu_{j, k}
$$

The weighting scheme used in the new exchange rate indexes is based on the three submeasures of competitiveness: $\mu_{U S, k}, \epsilon_{U S, k}, \tau_{U S, k}$. These three submeasures are also currently included in the trade model used by the staff for forecasting purposes, with the bilateral import shares used to aggregate foreign prices and exchange rates in the non-oil import sector and both the bilateral export shares and the thirdcountry weights used to aggregate foreign prices and exchange rates in the nonagricultural export sector.
Aggregation of the three submeasures of competitiveness into a single currency weight according to equation 2 requires information about the share of all goods sold in home markets that are domestically produced, $m_{j, j}$. Because such information is not readily available, particularly on a timely basis, we take a pragmatic approach to the aggregation. The two export sector weights, $\epsilon_{U S, k}$ and $\tau_{U S, k}$, are averaged with equal weighting. Empirical work done on the staff trade model for the broad index currencies shows that an equal weighting performs well in the core U.S. export sector and provides some rationale for the equal treatment in the new exchange rate indexes. ${ }^{8}$ Furthermore, the International Monetary Fund also uses equal weighting of its comparable export sector weights in its exchange rate index. Lacking any similar empirical work to support the aggregation of the import sector measure, $\mu_{U S, k}$, and the export sector measures, the staff chose to aggregate these two components with equal weights, based on aesthetic considerations of simplicity and symmetry. Thus, the weights, $w_{U S, k}$, used in the new exchange rate indexes are a fixed average of the import share weights and the two types of export weights:

$$
w_{U S, k}=\frac{1}{2} \mu_{U S, k}+\frac{1}{2}\left(\frac{1}{2} \epsilon_{U S, k}+\frac{1}{2} \tau_{U S, k}\right)
$$

8. Core exports are merchandise exports other than agricultural goods, computers, and semiconductors. 